\title{
Prevalence and estimation of hepatitis $B$ and $C$ infections in the WHO European Region: a review of data focusing on the countries outside the European Union and the European Free Trade Association
}

\author{
V. D. HOPE ${ }^{1,2 *}$, I. ERAMOVA ${ }^{3}$, D. CAPURRO ${ }^{3}$ AND M. C. DONOGHOE \\ ${ }^{1}$ Centre for Research on Drugs \& Health Behaviour, London School of Hygiene \& Tropical Medicine, \\ London, UK \\ ${ }^{2}$ Centre for Infectious Disease Surveillance and Control, Public Health England, London, UK \\ ${ }^{3}$ HIVIAIDS, Sexually Transmitted Infections and Viral Hepatitis Programme, World Health Organization \\ (WHO) Regional Office for Europe, Copenhagen, Denmark
}

Received 21 December 2012; Final revision 1 February 2013; Accepted 26 March 2013; first published online 29 May 2013

\section{SUMMARY}

Knowledge of hepatitis $\mathrm{B}$ and $\mathrm{C}$ prevalence, and numbers infected, are important for planning responses. Published HBsAg and anti-HCV prevalences for the $20 \mathrm{WHO}$ European Region countries outside the EU/EFTA were extracted, to complement published data for the EU/EFTA. The general population prevalence of HBsAg (median 3.8\%, mean $5 \cdot 0 \%$, seven countries) ranged from $1 \cdot 3 \%$ (Ukraine) to $13 \%$ (Uzbekistan), and anti-HCV (median $2 \cdot 3 \%$, mean $3.8 \%, 10$ countries) from $0 \cdot 5 \%$ (Serbia, Tajikistan) to $13 \%$ (Uzbekistan). People who inject drugs had the highest prevalence of both infections (HBsAg: median 6.8\%, mean 8.2\%, 13 countries; anti-HCV: median 46\%, mean 46\%, 17 countries), and prevalence was also elevated in men who have sex with men and sex workers. Simple estimates indicated 13.3 million (1.8\%) adults have HBsAg and 15.0 million (2.0\%) HCV RNA in the WHO European Region; prevalences were higher outside the EU/EFTA countries. Efforts to prevent, diagnose, and treat these infections need to be maintained and improved.

This article may not be reprinted or reused in any way in order to promote any commercial products or services.

Key words: Epidemiology, European Region, hepatitis B, hepatitis C, prevalence.

\section{INTRODUCTION}

Infection with the hepatitis B and C viruses (HBV and $\mathrm{HCV}$ ) causes significant morbidity and mortality. Even though HBV infection can be prevented through vaccination, the World Health Organization (WHO) has estimated that globally around 240 million people are chronically infected [1,2] with between 500000 and 700000 deaths each year $[1,3]$. WHO estimates also indicate that $2-3 \%$ of the world's population are

\footnotetext{
* Author for correspondence: Dr V. D. Hope, Centre for Research on Drugs \& Health Behaviour, London School of Hygiene \& Tropical Medicine, London, UK.

(Email: vivian.hope@1shtm.ac.uk)
}

HCV-infected, equating to $120-170$ million people [4]. About 1.0 million people die annually $(\sim 2.7 \%$ of all deaths) from causes related to viral hepatitis, most commonly liver disease, including liver cancer [5]. An estimated $57 \%$ of liver cirrhosis cases and $78 \%$ of primary liver cancers result from HBV or $\mathrm{HCV}$ infection [6]. Co-infections with HIV are an increasing problem in countries with HIV epidemics in people who inject drugs (PWID), and in those treated with HIV anti-retrovirals, and underlying viral hepatitis is becoming a major cause of death [5].

Globally there are geographical variations in the extent of both HBV and HCV infection including within Europe [4]. In the European Union (EU) and 
European Free Trade Association (EFTA) area, prevalence in the general population varies from $0 \cdot 4 \%$ to $5 \cdot 2 \%$ for anti-HCV and from $0 \cdot 1 \%$ to $5 \cdot 6 \%$ for HBsAg [7]. Hepatitis prevalence in the rest of the WHO European Region, mainly eastern Europe and central Asia countries, has not been assessed even though this part of the Region has recently experienced an accelerating HIV epidemic and an increase in the population of PWID [8].

$\mathrm{HBV}$ and $\mathrm{HCV}$ are bloodborne viruses that are easily transmitted through blood-to-blood contact [2, 9-11]. Parenteral routes, particularly injecting drug use or poor hygiene in clinical settings, are major sources of transmission [2, 9-12]. HBV can also be transmitted sexually, and this route has also been reported for HCV in certain circumstances [10, 13]. Perinatal transmission of both HBV and HCV can also occur $[2,9,10]$.

The majority of adults infected with HBV spontaneously resolve their infection and develop protective immunity [11]. Less commonly chronic infection results and, in rare cases, causes potentially fatal acute liver failure [11]. In contrast to $\mathrm{HBV}$, the majority of HCV-infected adults develop chronic disease [14]. Those with chronic infections remain infectious to others and are at risk of developing serious liver disease such as cirrhosis or hepatocellular cancer $[15,16]$. The available antiviral treatments for both HBV and $\mathrm{HCV}$ infections have increased and become more effective $[17,18]$. Treatment may also have a role in prevention through reducing the pool of infectious people [19].

As chronic HBV and HCV infections are largely asymptomatic, many patients who might benefit from treatment remain undetected [20]. Efforts are needed to detect those infected and who would benefit from treatment, so that the costly sequelae of infection can be reduced [21, 22]. To target casefinding it is necessary to know which population groups are most affected; and information on the likely numbers infected is needed for healthcare planning, for example, to assess the cost of providing treatment. Examination of these at a regional level allows comparison of the burden between countries as well as informing international responses.

The aims of this study were to: $(a)$ assess the prevalence of $\mathrm{HBV}$ and $\mathrm{HCV}$ infection in the WHO European Region countries outside the EU/EFTA through a literature review; $(b)$ generate simple estimates of the numbers living with $\mathrm{HBV}$ and $\mathrm{HCV}$ infection in these countries, and (c) to compare this burden with that in the rest of the WHO European Region obtained from published data [7].

\section{MATERIALS AND METHODS}

\section{Literature review}

Studies that had measured HBV and HCV seroprevalence since 2000 were identified through a literature review. To be included, studies had to: $(a)$ have tested a biological sample (self-reports were excluded) to measure prevalence of $\mathrm{HBsAg}$ or anti-HCV in a WHO European Region country outside the EU/ EFTA area $(n=20$, Table 1); $(b)$ do so in one or more of these adult population groups: general population, blood donors, pregnant women, PWID, men who have sex with men (MSM), and sex workers; and (c) have been published from 2000 to 2010 inclusive. Studies not meeting these criteria or reporting sample sizes $<100$ were excluded.

Medline and EMBASE were searched for studies on the prevalence of HBV and HCV (see Supplementary online material for search terms). The grey literature were indentified through searches of documents held by the WHO Regional Office for Europe, the European Monitoring Centre for Drugs and Drug Addition (EMCDDA) website, and the sources identified in a systematic review on HIV in the WHO European Region - which had systematically collected data on seroprevalence studies (including those with a focus on viral hepatitis) [8]. Bibliographies were checked for further sources. The titles and abstracts were first reviewed to identify relevant publication (in English or Russian), the full text was then assessed for inclusion and data extracted (including secondary reports). Data relating to screening of first-time blood donors was obtained from the Council of Europe report [23].

The prevalences in pregnant women were combined with the general population data. The nature of this population, women of child-bearing age, could mean that the prevalence might not reflect that overall in the general population, particularly if prevalence differs by gender or age, or if fertility rates are higher in migrant groups with higher prevalences; however, we have assumed that such differences are likely to be small overall. Prevalence in first-time blood donors was not combined with the general population data, as blood donors are a highly select group. In most countries those who may have been at risk of infection with bloodborne viruses are excluded from giving blood, thus blood donors are usually likely to be at lower risk overall than the general population.

A 'selected prevalence' estimate in the general population was obtained for each country using the 
Table 1. Number and geographical coverage of studies that had measured the prevalence of hepatitis B surface antigen (HBsAg) or antibodies to the hepatitis $C$ virus (anti-HCV) in each population group by country: countries in the WHO European Region outside EUIEFTA

\begin{tabular}{|c|c|c|c|c|c|c|c|c|}
\hline \multirow[b]{3}{*}{ Country } & \multicolumn{4}{|c|}{ General population } & \multicolumn{4}{|c|}{ Blood donors } \\
\hline & \multicolumn{2}{|l|}{ HBsAg } & \multicolumn{2}{|c|}{ Anti-HCV } & \multicolumn{2}{|l|}{ HBsAg } & \multicolumn{2}{|c|}{ Anti-HCV } \\
\hline & $\begin{array}{l}\text { No. of } \\
\text { studies }\end{array}$ & $\begin{array}{l}\text { Coverage } \\
\text { of studies }\end{array}$ & $\begin{array}{l}\text { No. of } \\
\text { studies }\end{array}$ & $\begin{array}{l}\text { Coverage } \\
\text { of studies }\end{array}$ & $\begin{array}{l}\text { No. of } \\
\text { studies }\end{array}$ & $\begin{array}{l}\text { Coverage } \\
\text { of studies }\end{array}$ & $\begin{array}{l}\text { No. of } \\
\text { studies }\end{array}$ & $\begin{array}{l}\text { Coverage } \\
\text { of studies }\end{array}$ \\
\hline Albania & 3 & $\begin{array}{l}\text { National }(x 2) \\
1 \text { city/area }\end{array}$ & 1 & 1 city/area & 2 & 1 city/area, n.s. & 2 & 1 city/area, n.s. \\
\hline Armenia & 0 & & 0 & & 0 & & 0 & \\
\hline Azerbaijan & 0 & & 0 & & 0 & & 0 & \\
\hline Belarus & 0 & & 0 & & 0 & & 0 & \\
\hline Bosnia \& Herzegovina & 0 & & 0 & & 1 & National & 2 & $\begin{array}{l}\text { National, } \\
1 \text { city/area }\end{array}$ \\
\hline Croatia & 0 & & 0 & & 1 & National & 1 & National \\
\hline Georgia & 0 & & 1 & 1 city/area & 0 & & 0 & \\
\hline Israel & 0 & & 0 & & 1 & National & 1 & National \\
\hline Kazakhstan & 1 & 1 city/area & 2 & $\begin{array}{l}\text { National, } \\
1 \text { city/area }\end{array}$ & 1 & National & 0 & \\
\hline Kyrgyzstan & 0 & & 1 & 2 cities/areas & 0 & & 0 & \\
\hline Montenegro & 0 & & 0 & & 1 & National & 1 & National \\
\hline Republic of Moldova & 0 & & 0 & & 0 & & 0 & \\
\hline Russian Federation & 2 & $\begin{array}{l}\text { ?National, } \\
1 \text { city/area }\end{array}$ & 2 & $\begin{array}{l}\text { ?National, } \\
1 \text { city/area }\end{array}$ & 1 & 1 city/area & 1 & 1 city/area \\
\hline Serbia (incl. Kosovo*) & 1 & 1 city/area & 1 & 1 city/area & 1 & 1 city/area & 1 & 1 city/area \\
\hline Tajikistan & 0 & & 1 & Multi-site & 1 & National & 1 & National \\
\hline $\begin{array}{l}\text { The former Yugoslav } \\
\text { Republic of Macedonia }\end{array}$ & 0 & & 0 & & 1 & 1 city/area & 1 & 1 city/area \\
\hline Turkey & 9 & $\begin{array}{l}\text { Multi-site (x2), } \\
1 \text { city/area (x7) }\end{array}$ & 7 & $\begin{array}{l}\text { Multi-site, } \\
1 \text { city/area (x6) }\end{array}$ & 3 & $\begin{array}{l}\text { National, } \\
1 \text { city/area (x2) }\end{array}$ & 3 & $\begin{array}{l}\text { National, } \\
1 \text { city/area (x2) }\end{array}$ \\
\hline Turkmenistan & 0 & & 0 & & 0 & & 0 & \\
\hline Ukraine & 4 & Unclear & 3 & Unclear & 3 & Unclear & 2 & Unclear \\
\hline Uzbekistan & 1 & Multisite & 1 & Multisite & 1 & Multisite & 2 & Multisite \\
\hline Total & 21 & & 20 & & 18 & & 18 & \\
\hline
\end{tabular}


Table 1 (cont.)

(b) People who injecting drugs (PWID)

\begin{tabular}{|c|c|c|c|c|}
\hline & \multicolumn{4}{|l|}{ PWID } \\
\hline & \multicolumn{2}{|l|}{ HBsAg } & \multicolumn{2}{|c|}{ Anti-HCV } \\
\hline & $\begin{array}{l}\text { No. of } \\
\text { studies }\end{array}$ & $\begin{array}{l}\text { Coverage } \\
\text { of studies }\end{array}$ & $\begin{array}{l}\text { No. of } \\
\text { studies }\end{array}$ & Coverage of studies \\
\hline Albania & 1 & 1 city/area & 2 & 1 city/area \\
\hline Armenia & 0 & & 0 & \\
\hline Azerbaijan & 1 & Multi-site & 2 & Multi-site, 2 cities/areas \\
\hline Belarus & 1 & Multi-site & 2 & Multi-site, 1 city/area \\
\hline Bosnia \& Herzegovina & 2 & Multi-site & 2 & Multi-site \\
\hline Croatia & 3 & $\begin{array}{l}\text { National multi-site, } \\
1 \text { city/area }\end{array}$ & 3 & National, multi-site, 1 city/area \\
\hline Georgia & 3 & 1 city/area & 4 & Multi-site, 1 city/area (x3) \\
\hline Israel & 1 & National & 1 & National \\
\hline Kazakhstan & 1 & 2 cities/areas & 2 & National, 2 cities/areas \\
\hline Kyrgyzstan & 0 & & 2 & Multi-site, 2 cities/areas \\
\hline Montenegro & 1 & Unclear & 2 & 1 city/area, unclear \\
\hline Republic of Moldova & 1 & National & 1 & National \\
\hline Russian Federation & 2 & 2 cities/areas, 1 city/area & 16 & Multi-site (x2), 1 city/area (x12), unclear (x2) \\
\hline Serbia (incl. Kosovo*) & 1 & 1 city/area & 3 & Multi-site, 1 city/area (x2) \\
\hline Tajikistan & 0 & & 2 & Multi-site, 1 city/area \\
\hline $\begin{array}{l}\text { The former Yugoslav Republic } \\
\text { of Macedonia }\end{array}$ & 0 & & 0 & \\
\hline Turkey & 1 & Multi-site & 1 & 1 city/area \\
\hline Turkmenistan & 0 & & 0 & \\
\hline Ukraine & 3 & $\begin{array}{c}1 \text { city/area }(\mathrm{x} 1) \\
\text { unclear }(\mathrm{x} 2)\end{array}$ & 6 & 1 city/area $(\mathrm{x} 4)$, unclear $(\mathrm{x} 2)$ \\
\hline Uzbekistan & 0 & & 2 & National multi-site \\
\hline Total & 22 & & 53 & \\
\hline
\end{tabular}


(c) Men who have sex with men (MSM) and sex workers

\begin{tabular}{|c|c|c|c|c|c|c|c|c|}
\hline & \multicolumn{4}{|l|}{ MSM } & \multicolumn{4}{|c|}{ Sex workers } \\
\hline & \multicolumn{2}{|l|}{ HBsAg } & \multicolumn{2}{|c|}{ Anti-HCV } & \multicolumn{2}{|l|}{ HBsAg } & \multicolumn{2}{|c|}{ Anti-HCV } \\
\hline & $\begin{array}{l}\text { No. of } \\
\text { studies }\end{array}$ & $\begin{array}{l}\text { Coverage } \\
\text { of studies }\end{array}$ & $\begin{array}{l}\text { No. of } \\
\text { studies }\end{array}$ & $\begin{array}{l}\text { Coverage } \\
\text { of studies }\end{array}$ & $\begin{array}{l}\text { No. of } \\
\text { studies }\end{array}$ & $\begin{array}{l}\text { Coverage } \\
\text { of studies }\end{array}$ & $\begin{array}{l}\text { No. of } \\
\text { studies }\end{array}$ & $\begin{array}{l}\text { Coverage } \\
\text { of studies }\end{array}$ \\
\hline Albania & 1 & 1 city/area & 0 & & 0 & & 0 & \\
\hline Armenia & 0 & & 0 & & 0 & & 0 & \\
\hline Azerbaijan & 1 & 1 city/area & 1 & 1 city/area & 1 & Multi-site & 1 & Multi-site \\
\hline Belarus & 0 & & 0 & & 0 & & 0 & \\
\hline Bosnia \& Herzegovina & 1 & National & 1 & National & 1 & National & 1 & National \\
\hline Croatia & 1 & 1 city/area & 2 & 1 city/area, national & 0 & & 1 & National \\
\hline Georgia & 1 & 1 city/area & 1 & 1 city/area & 0 & & 0 & \\
\hline Israel & 0 & & 0 & & 0 & & 0 & \\
\hline Kazakhstan & 0 & & 1 & National & 0 & & 1 & National \\
\hline Kyrgyzstan & 0 & & 1 & National & 0 & & 3 & $\begin{array}{l}\text { National multi-site, } \\
1 \text { city/area }\end{array}$ \\
\hline Montenegro & 0 & & 0 & & 0 & & 0 & \\
\hline Republic of Moldova & 0 & & 1 & 1 city/area & 0 & & 1 & 1 city/area \\
\hline Russian Federation & 0 & & 1 & 2 cities/areas & 0 & & 3 & $\begin{array}{l}\text { Multi-site, } \\
1 \text { city/area (x2) }\end{array}$ \\
\hline Serbia (incl. Kosovo*) & 1 & 1 city/area & 1 & 1 city/area & 1 & 1 city/area & 1 & 1 city/area \\
\hline Tajikistan & 0 & & 0 & & 0 & & 1 & National \\
\hline $\begin{array}{l}\text { The former Yugoslav Republic } \\
\text { of Macedonia }\end{array}$ & 0 & & 0 & & 0 & & 0 & \\
\hline Turkey & 1 & Multi-site & 0 & & 2 & $\begin{array}{l}\text { Multi-site, } \\
1 \text { city/area }\end{array}$ & 1 & 1 city/area \\
\hline Turkmenistan & 0 & & 0 & & 0 & & 0 & \\
\hline Ukraine & 1 & Unclear & 1 & Unclear & 1 & Unclear & 1 & Unclear \\
\hline Uzbekistan & 0 & & 0 & & 0 & & 2 & $\begin{array}{l}\text { Multi-site, } \\
1 \text { city/area }\end{array}$ \\
\hline Total & 8 & & 11 & & 6 & & 17 & \\
\hline
\end{tabular}

EU/EFTA, European Union and European Free Trade Association area; n.s., not stated.; '?', preceding a detail indicates that the information available on this item in the source was limited.

* According to United Nations Security Council Resolution 1244 (1999). 
Table 2. Algorithm used to select a national prevalence

Prevalences were selected using the following hierarchy:

(1) National studies.

(2) Studies with multiple sites across the country.

(3) Regional/city levels studies.

If more there was than one study (for example several multi-site studies) then the weight mean was used (or mean if this could not be calculated) to obtain the selected prevalence.

algorithm in Table 2. This was applied to other groups if sufficient studies were identified.

\section{Simple estimates of number infected}

The total number of adults currently infected with HBV and HCV was estimated by applying the HBsAg and anti-HCV prevalences to the 2008 national adult (aged $\geqslant 15$ years) population estimates [24]. In countries that had a selected prevalence in blood donors only, the prevalence in the general population was simply imputed from the blood-donor data. This was done by using the median ratio of the blooddonor estimates to the general population estimates for those countries with selected estimates for both of these groups. For countries with no general population and no blood-donor estimate the median of the selected general population's prevalences was used. Medians were used as the distributions were skewed, with a small number of countries having a much higher prevalence than the rest; the median thus gives a more conservative estimate than would be obtained using the mean. For HCV, $74 \%$ of those anti-HCV positive were assumed to have current infection [25].

To obtain comparable simple estimates of the numbers living with these infections in the EU/EFTA countries the same method was applied to published data ( $n=30$, excluding four with populations $<100000$ ). Prevalence in first time blood donors was taken from the Council of Europe report [23], with additional data from an European Centre for Disease Prevention and Control (ECDC) review [7] (HBsAg prevalence for 27 countries, anti-HCV for 26). General population prevalences were obtained from the ECDC review, this had obtained selected prevalences for the EU/EFTA countries using a similar method (13 countries HBsAg, 12 anti-HCV) [7].
The numbers of current PWID infected with HBV and HCV were obtained by applying the selected PWID HBsAg and anti-HCV prevalences to published national estimates of the number of current injectors [26, 27]. Where national estimates of the current injecting population were not available the median of the national prevalences of injecting drug use was used to impute the number of PWID from the adult population data. For countries with no HBsAg or anti-HCV prevalence estimate for PWID the median of the selected national prevalences was used. Medians were again used as the distributions were skewed. As with the general population for $\mathrm{HCV}, 74 \%$ of those anti-HCV positive were assumed to have current infection [25].

To obtain comparable simple estimates of the number of PWID living with these infections in the EU/EFTA countries prevalence data from studies undertaken since 1999 was downloaded from the EMCDDA website [27] (all EU states and Norway report HBV and HCV seroprevalences for PWID to EMCDDA) and literature searches for Switzerland and Iceland (not members of EMCDDA). Selected prevalence estimates were then derived using the same algorithm as above. Numbers were then estimated using the same approach, including imputations for missing data, as for the countries outside EU/EFTA.

\section{RESULTS}

After accounting for studies reported by more than one publication, a total 86 sources were identified (Supplementary Fig. S1).

\section{Prevalence: general population and blood donors}

Twenty-one studies, undertaken in seven countries ( $35 \%$ of total), had measured HBsAg prevalence in a group representing the general population (Table 1): 11 recruited from the general population, five pregnant women, and five other groups (Supplementary Table S1). Half of these studies had recruited from one city/area (Table 1). Thirteen countries $(65 \%)$ had measured HBsAg prevalence in blood donors (18 studies, 39\% had national coverage, Table 1). Together the general population and blood donor studies covered 13 countries. The study HBsAg prevalences ranged from $0 \cdot 1 \%$ (blood donors, Bosnia \& Herzegovina) to $13 \%$ (general population, Uzbekistan, Supplementary Table S1). The selected country 
HBsAg prevalence estimates (Table 3, Fig. 1) ranged from $1 \cdot 3 \%$ to $13 \%$ for the general population (median $3 \cdot 4 \%$, mean $5 \cdot 0 \%$ ) and from $0 \cdot 1 \%$ to $8.4 \%$ for blood donors (median $1 \cdot 1 \%$, mean $2 \cdot 2 \%$ ). The selected general population prevalence was higher than the selected blood-donor prevalence in five of the seven countries with both (Table 3), the median of the ratio between these was $1 \cdot 4$ (range $0 \cdot 57-2 \cdot 6$, mean $1 \cdot 6$ ).

Ten countries $(50 \%)$ had measured the anti-HCV prevalence in groups representing the general population (20 studies: nine recruited from the general population, six pregnant women, five other groups), with two-thirds of these studies covering one city/area (Table 1). Twelve countries (60\%) had measured anti-HCV prevalence in blood donors (18 studies, $39 \%$ recruited from one city/area, Table 1). Together these measures covered 15 countries (75\%). The study anti-HCV prevalences ranged from $0.03 \%$ (blood donors, Bosnia \& Herzegovina) to $13 \%$ (general population, Uzbekistan, Supplementary Table S1). The selected country estimates (Table 3, Fig. 1) ranged from $0.5 \%$ to $13 \%$ for the general population (median $2 \cdot 3 \%$, mean $4 \cdot 3 \%$ ) and from $0.03 \%$ to $6 \cdot 4 \%$ for blood donors (median $0 \cdot 46 \%$, mean $1 \cdot 3 \%$ ). The selected general population prevalence was higher than the selected blood-donor prevalence in six of the seven countries with measures of both (Table 3), the median of the ratio between these was $2 \cdot 1$ (range $0 \cdot 17-9 \cdot 2$, mean $3 \cdot 0$ ).

\section{Prevalence: PWID}

Fourteen $(70 \%)$ countries had measured HBsAg prevalence and $17(85 \%)$ anti-HCV prevalence in PWID (Table 1). In total 54 studies were identified, including 30 that had recruited from community settings; eight from needle and syringe programmes, low-threshold facilities, harm reduction, or outreach services; three from addiction treatment settings; four through other service types; and five through mixed settings (setting was unclear in four, see Supplementary Table S2). The mean sample size was 650 (range 60-4860, median 319). Twenty-two studies had measured HBsAg (38\% recruited in one city/area, Table 1) and 53 studies anti-HCV prevalence $(53 \%$ recruited in one city/area, Table 1). The study HBsAg prevalences ranged from $0 \%$ to $34 \%$, and the anti-HCV prevalences from $5 \cdot 3 \%$ to $95 \%$ (Supplementary Table S2). The selected country prevalence estimates (Table 4, Fig. 1) ranged from $0.8 \%$ to $31 \%$ for HBsAg (median $6.8 \%$, mean $9 \cdot 2 \%$ ) and from $5 \cdot 3 \%$ to $73 \%$ for anti-HCV (median $46 \%$, mean $46 \%$ ).

\section{Prevalence: MSM}

Thirteen studies were found that had measured the prevalence of either HBsAg or anti-HCV in MSM (Supplementary Table S3). The samples sizes ranged from 61-741 (mean 235, median 157), and the majority had recruited MSM from community settings $(11,85 \%)$. Eight $(40 \%)$ countries had undertaken a single study that had measured the HBsAg prevalence in MSM (five recruited from one city/area, Table 1). The prevalences ranged from $0 \%$ to $18 \%$ (Supplementary Table S3) with a median of $6.4 \%$ (mean 6.9\%). Eleven studies (from 10 countries, $50 \%$ ) reported anti-HCV prevalence in MSM (five recruited from one city/area, Table 1). The median of study anti-HCV prevalence was $4 \cdot 2 \%$ (mean $7 \cdot 8 \%$, range $0-16 \%$, Supplementary Table S3).

\section{Prevalence: sex workers}

Seventeen studies (Supplementary Table S4) had measured the prevalence of either HBsAg or anti$\mathrm{HCV}$ in sex workers: samples sizes ranged from 138-2249 (mean 591, median 315). Almost half of the studies (eight, 47\%) recruited sex workers from community settings, with four recruiting through services $(23 \%)$ and two $(12 \%)$ from both community settings and services (setting unclear for three, Supplementary Table S4). Six studies, from five countries $(25 \%)$, reported an HBsAg prevalence in sex workers (two recruited from one city/area, Table 1); prevalence ranged from $2 \%$ to $18 \%$ (Supplementary Table S4), the median was $2 \cdot 9 \%$ (mean $6 \cdot 1 \%$ ). Seventeen studies from 12 countries $(60 \%)$, reported an anti-HCV prevalence in sex workers (seven recruited from one city/area, Table 1); prevalences ranged from $2.4 \%$ to $40 \%$ (median $11 \%$, mean $14 \%$ ).

\section{Imputation of general population prevalence from blood donors}

General population prevalence estimates were imputed from the blood-donor prevalence using the median ratio of the general population to the blooddonor prevalence derived from those countries with both (Table 3). Applying this ratio to the blooddonor prevalence in those countries from which it was derived, gave a median difference between the countries measured and the imputed general population prevalence of $0 \cdot 004 \%$ for $\mathrm{HBsAg}$ (range $-3 \cdot 3 \%$ to $6 \cdot 2 \%$, mean $0 \cdot 6 \%$ ) and $-0.02 \%$ for anti-HCV 
Table 3. Simple estimates of the number of adults with hepatitis B surface antigen (HBsAg) and hepatitis C virus (HCV) in WHO European Region

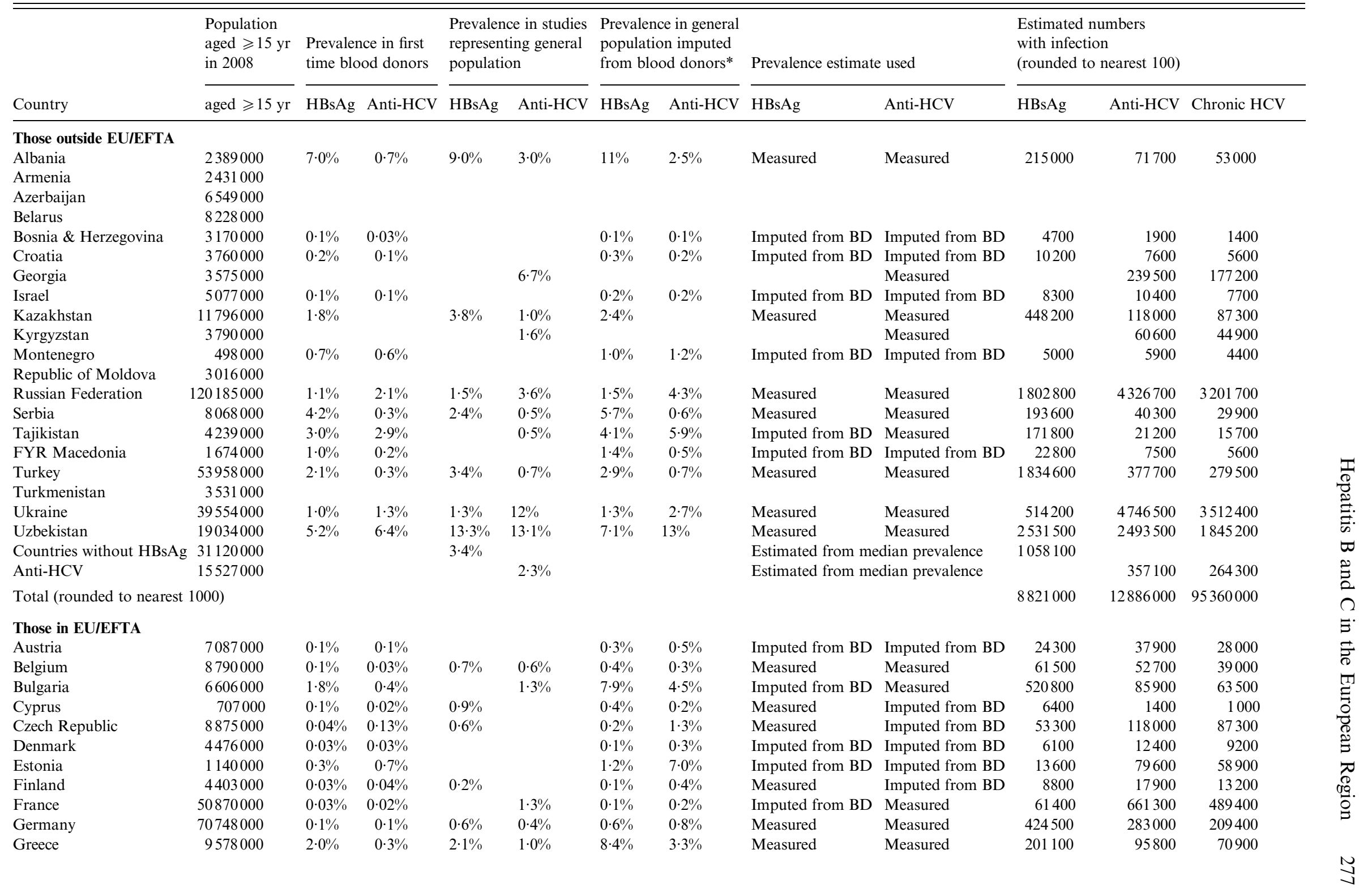


Table 3 (cont.)

\begin{tabular}{|c|c|c|c|c|c|c|c|c|c|c|c|c|}
\hline \multirow[b]{2}{*}{ Country } & \multirow{2}{*}{$\begin{array}{l}\text { Population } \\
\text { aged } \geqslant 15 \mathrm{yr} \\
\text { in } 2008 \\
\text { aged } \geqslant 15 \mathrm{yr}\end{array}$} & \multicolumn{2}{|c|}{$\begin{array}{l}\text { Prevalence in first } \\
\text { time blood donors }\end{array}$} & \multicolumn{2}{|c|}{$\begin{array}{l}\text { Prevalence in studies } \\
\text { representing general } \\
\text { population }\end{array}$} & \multicolumn{2}{|c|}{$\begin{array}{l}\text { Prevalence in general } \\
\text { population imputed } \\
\text { from blood donors* }\end{array}$} & \multicolumn{2}{|c|}{ Prevalence estimate used } & \multicolumn{3}{|c|}{$\begin{array}{l}\text { Estimated numbers } \\
\text { with infection } \\
\text { (rounded to nearest 100) }\end{array}$} \\
\hline & & HBsAg & Anti-HCV & HBsAg & Anti-HCV & HBsAg & Anti-HCV & HBsAg & Anti-HCV & HBsAg & Anti-HCV & Chronic HCV \\
\hline Hungary & 8511000 & $0 \cdot 0 \%$ & $0 \cdot 3 \%$ & & & $0 \cdot 0 \%$ & $3 \cdot 1 \%$ & Imputed from BD & Imputed from $\mathrm{BD}$ & 2600 & 267400 & 197900 \\
\hline Iceland & 249000 & & & & & & & & & & & \\
\hline Ireland & 3506000 & $0 \cdot 01 \%$ & $0 \cdot 01 \%$ & $0 \cdot 1 \%$ & & $0 \cdot 1 \%$ & $0 \cdot 1 \%$ & Measured & Imputed from BD & 3500 & 3100 & 2300 \\
\hline Italy & 51260000 & $0 \cdot 4 \%$ & & $1 \cdot 4 \%$ & $5 \cdot 2 \%$ & $1 \cdot 7 \%$ & & Measured & Measured & 717600 & 2665500 & 1972500 \\
\hline Latvia & 1943000 & & & & & & & & & & & \\
\hline Lithuania & 2823000 & $0 \cdot 6 \%$ & $1 \cdot 0 \%$ & & & $2 \cdot 6 \%$ & $10 \cdot 3 \%$ & Imputed from BD & Imputed from $\mathrm{BD}$ & 73900 & 289800 & 214500 \\
\hline Luxembourg & 395000 & $0 \cdot 1 \%$ & $0 \cdot 1 \%$ & & & $0 \cdot 4 \%$ & $0 \cdot 6 \%$ & Imputed from BD & Imputed from $\mathrm{BD}$ & 1700 & 2500 & 1800 \\
\hline Malta & 342000 & & & & & & & & & & & \\
\hline Netherlands & 13553000 & $0 \cdot 1 \%$ & $0 \cdot 02 \%$ & $0 \cdot 1 \%$ & $0 \cdot 4 \%$ & $0 \cdot 3 \%$ & $0 \cdot 2 \%$ & Measured & Measured & 13600 & 54200 & 40100 \\
\hline Norway & 3862000 & $0 \cdot 03 \%$ & $0 \cdot 03 \%$ & & & $0 \cdot 1 \%$ & $0 \cdot 4 \%$ & Imputed from BD & Imputed from $\mathrm{BD}$ & 4400 & 13600 & 10000 \\
\hline Poland & 32389000 & $0 \cdot 5 \%$ & $0 \cdot 2 \%$ & & $1.9 \%$ & $2 \cdot 0 \%$ & $1.9 \%$ & Imputed from $\mathrm{BD}$ & Measured & 659800 & 615400 & 455400 \\
\hline Portugal & 9076000 & $0 \cdot 1 \%$ & $0 \cdot 2 \%$ & & & $0 \cdot 4 \%$ & $1 \cdot 7 \%$ & Imputed from BD & Imputed from BD & 36900 & 157000 & 116100 \\
\hline Romania & 18157000 & $3 \cdot 7 \%$ & $0 \cdot 9 \%$ & $5 \cdot 6 \%$ & $3 \cdot 5 \%$ & $15 \cdot 8 \%$ & $9 \cdot 2 \%$ & Measured & Measured & 1016800 & 635500 & 470300 \\
\hline Slovakia & 4536000 & $0 \cdot 1 \%$ & $0 \cdot 1 \%$ & $0.6 \%$ & & $0 \cdot 6 \%$ & $0 \cdot 5 \%$ & Measured & Imputed from $\mathrm{BD}$ & 27200 & 24000 & 17700 \\
\hline Slovenia & 1733000 & $0 \cdot 1 \%$ & $0 \cdot 03 \%$ & & & $0 \cdot 4 \%$ & $0 \cdot 4 \%$ & Imputed from BD & Imputed from $\mathrm{BD}$ & 7500 & 6100 & 4500 \\
\hline Spain & 37814000 & $0 \cdot 2 \%$ & $0 \cdot 1 \%$ & $1 \cdot 0 \%$ & $2 \cdot 0 \%$ & $0 \cdot 7 \%$ & $1 \cdot 4 \%$ & Measured & Measured & 378100 & 756300 & 559600 \\
\hline Sweden & 7641000 & $0 \cdot 05 \%$ & $0 \cdot 1 \%$ & $0 \cdot 2 \%$ & $0 \cdot 4 \%$ & $0 \cdot 2 \%$ & $0 \cdot 6 \%$ & Measured & Measured & 15300 & 30600 & 22600 \\
\hline Switzerland & 6335000 & $0 \cdot 2 \%$ & $0 \cdot 1 \%$ & & & $0 \cdot 7 \%$ & $0 \cdot 6 \%$ & Imputed from BD & Imputed from BD & 44800 & 40600 & 30000 \\
\hline United Kingdom & 50210000 & $0 \cdot 04 \%$ & $0 \cdot 04 \%$ & & $0 \cdot 7 \%$ & $0 \cdot 2 \%$ & $0 \cdot 4 \%$ & Imputed from BD & Measured & 86400 & 351500 & 260100 \\
\hline Countries without $\mathrm{HbsAg}$ & 2534000 & & & $0 \cdot 6 \%$ & & & & Estimated from mec & edian prevalence & 15200 & & \\
\hline Anti-HCV & 2534000 & & & & $1 \cdot 2 \%$ & & & Estimated from mec & dian prevalence & & 29100 & 21600 \\
\hline \multicolumn{4}{|c|}{ Total (rounded to nearest 1000) } & & & & & & & 4487000 & 7387900 & 5467000 \\
\hline \multicolumn{4}{|c|}{ Total Europe } & & & & & & & 13308000 & 20274000 & 15003000 \\
\hline \multicolumn{2}{|l|}{732137000} & & & & & & & & & $1 \cdot 8 \%$ & $2 \cdot 8 \%$ & $2 \cdot 0 \%$ \\
\hline
\end{tabular}

BD, Blood donors; FYR Macedonia, Former Yugoslav Republic of Macedonia; Anti-HCV, antibodies to the hpatitis C virus; EU/EFTA, European Union and European Free Trade Association area.

* Estimated using median of the national ratios of the general population prevalence to prevalence in blood donors. 

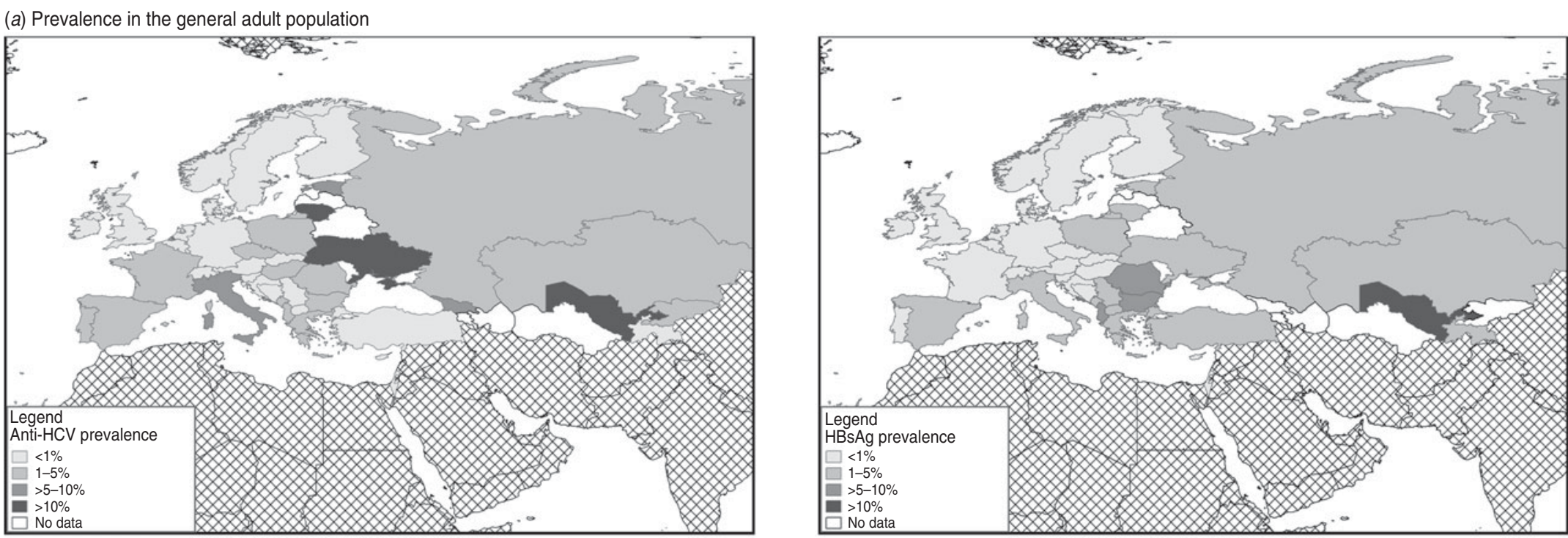

(b) Prevalence in people who inject drugs (PWID)

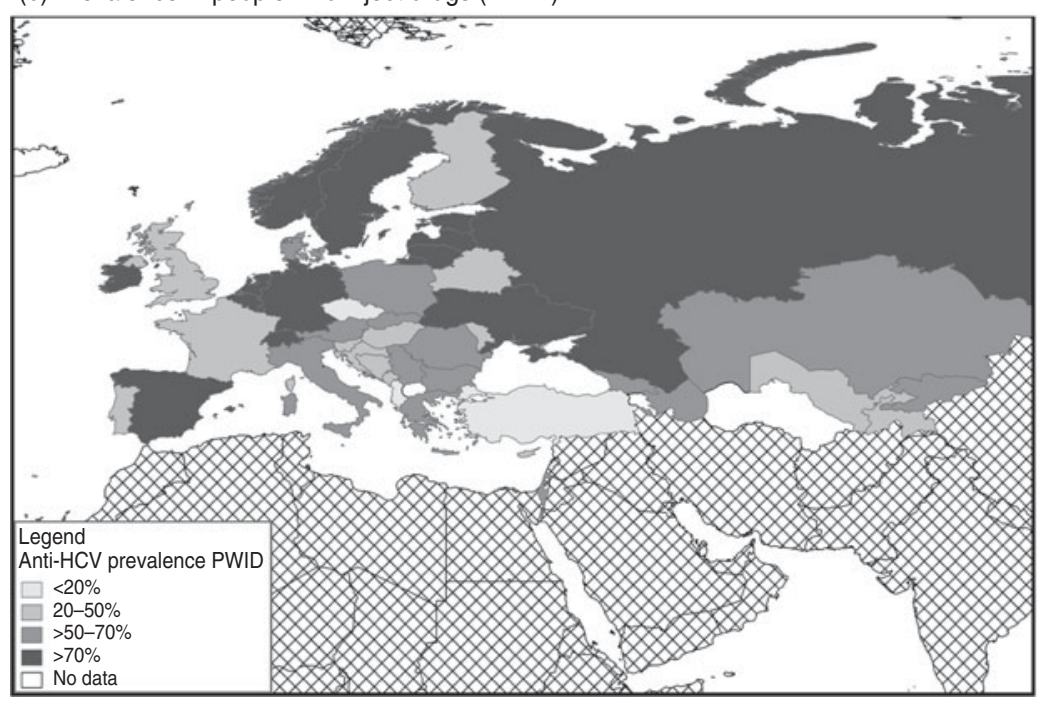

Hatched countries in maps are those outside the WHO Europeon Region.

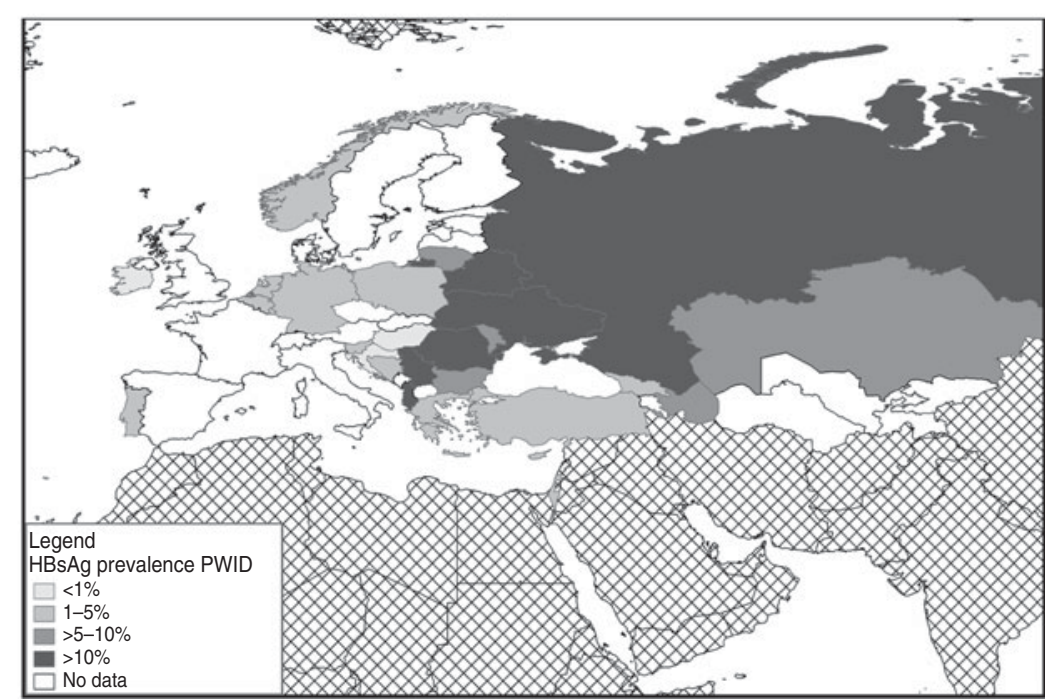

Fig. 1. Prevalence of antibodies to hepatitis C virus (anti-HCV) and hepatitis B surface antigen (HBsAg) in $(a)$ the general adult population; $(b)$ people who inject drugs (PWID) in the WHO European region, by country. Hatched areas on maps indicate countries outside the WHO European Region. 
Table 4. Estimates of number of current hepatitis $B$ and $C$ infections in the WHO European Region: EUIEFTA and non-EUIEFTA comparisons

\begin{tabular}{lllclrl}
\hline \hline & Adult population & $(\%)$ & Current HBV & $(\%)$ & Current HCV & $(\%)$ \\
\hline EU/EFTA* & 427615000 & $(58)$ & 4487000 & $(34)$ & 5467000 & $(36)$ \\
Non EU/EFTA $\dagger$ & 304522000 & $(42)$ & 8821000 & $(66)$ & 9536000 & $(64)$ \\
WHO European Region & 732137000 & $(100)$ & 13308000 & $(100)$ & 15003000 & $(100)$ \\
\hline \hline
\end{tabular}

EU/EFTA, European Union and European Free Trade Association area.

* Twenty-seven EU Member States: Austria, Belgium, Bulgaria, Cyprus, Czech Republic, Denmark, Estonia, Finland, France, Germany, Greece, Hungary, Ireland, Italy, Latvia, Lithuania, Luxembourg, Malta, The Netherlands, Poland, Portugal, Romania, Slovakia, Slovenia, Spain, Sweden, United Kingdom.

Four EEA/EFTA countries: Norway, Iceland, Liechtenstein, Switzerland.

$\dagger$ Albania, Armenia, Azerbaijan, Belarus, Bosnia \& Herzegovina, Croatia, Georgia, Israel, Kazakhstan, Kyrgyzstan, Montenegro, Republic of Moldova, Russian Federation, Serbia (incl. Kosovo), Tajikistan, The former Yugoslav Republic of Macedonia, Turkey, Turkmenistan, Ukraine.

(range $-5 \cdot 4 \%$ to $9 \cdot 3 \%$, mean $0 \cdot 7 \%$ ). This variability indicates that a country prevalence imputed this way should be treated with caution.

\section{Simple estimates of total numbers infected}

The selected and imputed prevalences obtained here were applied to population data to produce simple estimates of the numbers infected. These estimates indicate that of the $304 \cdot 5$ million adults living outside the EU/EFTA area $8 \cdot 8$ million $(2 \cdot 9 \%)$ have HBsAg and $9 \cdot 5$ million $(3 \cdot 1 \%)$ have HCV RNA (Table 3 ). Comparable estimates for the EU/EFTA countries obtained by applying the same method to published data [7] (Table 3, Fig. 1; the median ratio between the selected general population and the selected blood-donor prevalence used in the imputations was $4 \cdot 3$ for HBsAg and 11 for anti-HCV). These indicated that of the 427.6 million adults in the EU/EFTA countries 4.5 million $(1.0 \%)$ have $\mathrm{HBsAg}$ and $5 \cdot 5$ million $(1 \cdot 3 \%)$ have HCV RNA (Table 3 ). These levels are respectively around one-third and one half of the levels estimated for the area outside the EU/EFTA. Combining these simple estimates indicates that of the $732 \cdot 1$ million adults in the WHO European Region 13.3 million (1.8\%) have HBsAg and 15.0 million $(2 \cdot 0 \%)$ have HCV RNA; with two-thirds of those living with each infection outside the EU/EFTA area (Table 4).

\section{Simple estimates of total number of infected PWID}

The selected and imputed estimates of prevalence in PWID were used to derive simple estimates of the number of current PWID living with HBV and HCV infection outside the EU/EFTA. Considering the wide range in the estimated prevalences of injecting drug use $(0 \cdot 077-3 \cdot 6 \%)$ and in the prevalences of the two infections in PWID (see above) the imputed data should be viewed with great caution. These estimates indicate that of the estimated 3.2 million current PWID outside the EU/EFTA 0.7 million (21\%) have HBsAg and 1.5 milion (47\%) have HCV RNA (Table 5).

Comparable estimates for current PWID living in EU/EFTA countries were derived from published data [27] by applying the same method (Table 5, Fig. 1). These estimates for EU/EFTA should be viewed cautiously, as due to the substantial variability in the prevalences (injecting drug use: $0 \cdot 06-1 \cdot 2 \%$, median $0 \cdot 28 \%$, mean $0.31 \%$; HBsAg: $0 \cdot 3-10 \%$, median $3 \cdot 5 \%$, mean $3 \cdot 7 \%$; anti-HCV: $12-88 \%$, median $59 \%$, mean $58 \%$ ) the imputed data used here are likely to be subject to much uncertainty. The estimation process indicates that of the estimated 1.2 million current PWID in the EU/EFTA area $45000(3.7 \%)$ have HBsAg and 0.5 million (43\%) have HCV RNA (Table 5). The proportion with anti-HCV is comparable with the level outside of the EU/EFTA; however, the proportion with HBsAg is much lower (Table 4). Combining these estimates indicates that in current PWID (estimated 4.5 million) across the WHO European Region 0.7 million (15\%) have $\mathrm{HBsAg}$ and 2.0 million (44\%) have HCV RNA (Table 5).

\section{DISCUSSION}

Our simple estimates suggest that almost $1 / 50$ adults in the WHO European Region have HBV infection and a similar proportion chronic HCV. Outside of the EU/EFTA area prevalence was around three times higher for HBsAg and over twice as high for 
Table 5. Simple estimates of the number of people who inject drugs with hepatitis B surface antigen (HBsAg) and hepatitis C virus (HCV) in WHO European Region

\begin{tabular}{|c|c|c|c|c|c|c|c|c|c|}
\hline \multirow[b]{2}{*}{ Country } & \multirow[b]{2}{*}{$\begin{array}{l}\text { Population aged } \\
\geqslant 15 \mathrm{yr} \text { in } 2008\end{array}$} & \multicolumn{3}{|c|}{ Estimated number of current PWID* } & \multicolumn{2}{|c|}{ Prevalence } & \multicolumn{3}{|c|}{$\begin{array}{l}\text { Estimated numbers with infection } \\
\text { (rounded to nearest 100) }\end{array}$} \\
\hline & & Number & Prevalence & $\begin{array}{l}\text { Imputed from } \\
\text { median prevalence }\end{array}$ & $\mathrm{HBsAg}$ & Anti-HCV & HBsAg & Anti-HCV & $\begin{array}{l}\text { Chronic } \\
\mathrm{HCV}\end{array}$ \\
\hline \multicolumn{10}{|l|}{ Those outside EU/EFTA } \\
\hline Albania & 2389000 & & & 10000 & $15 \%$ & $13 \%$ & 1500 & 1300 & 900 \\
\hline Armenia & 2431000 & 2000 & $0 \cdot 08 \%$ & & & & & & \\
\hline Azerbaijan & 6549000 & 300000 & $4 \cdot 58 \%$ & & $5 \cdot 9 \%$ & $54 \%$ & 17700 & 162700 & 120400 \\
\hline Belarus & 8228000 & 6308 & $0 \cdot 08 \%$ & & $13 \%$ & $39 \%$ & 800 & 2500 & 1800 \\
\hline Bosnia and Herzegovina & 3170000 & 5500 & $0 \cdot 17 \%$ & & $2 \cdot 7 \%$ & $38 \%$ & 100 & 2100 & 1500 \\
\hline Croatia & 3760000 & 16740 & $0 \cdot 45 \%$ & & $0 \cdot 8 \%$ & $46 \%$ & 100 & 7700 & 5700 \\
\hline Georgia & 3575000 & 127833 & $3 \cdot 58 \%$ & & $2 \cdot 9 \%$ & $67 \%$ & 3700 & 85600 & 63400 \\
\hline Israel & 5077000 & & & 21000 & $4 \cdot 3 \%$ & $62 \%$ & 900 & 13000 & 9600 \\
\hline Kazakhstan & 11796000 & 100000 & $0 \cdot 85 \%$ & & $7 \cdot 9 \%$ & $60 \%$ & 7900 & 60000 & 44400 \\
\hline Kyrgyzstan & 3790000 & 25000 & $0.66 \%$ & & & $54 \%$ & & 13600 & 10000 \\
\hline Montenegro & 498000 & & & 2000 & & $38 \%$ & & 800 & 600 \\
\hline Republic of Moldova & 3016000 & 3810 & $0 \cdot 13 \%$ & & $6 \cdot 8 \%$ & $43 \%$ & 300 & 1600 & 1200 \\
\hline Russian Federation & 120185000 & 1825000 & $1 \cdot 52 \%$ & & $31 \%$ & $73 \%$ & 565800 & 1332300 & 985900 \\
\hline Serbia & 8068000 & 18000 & $0 \cdot 22 \%$ & & $15 \%$ & $52 \%$ & 2600 & 9400 & 6900 \\
\hline Tajikistan & 4239000 & 17000 & $0 \cdot 40 \%$ & & & $33 \%$ & & 5500 & 4100 \\
\hline FYR Macedonia & 1674000 & 2691 & $0 \cdot 16 \%$ & & & & & & \\
\hline Turkey & 53958000 & & & 226000 & $2 \cdot 9 \%$ & $5 \cdot 3 \%$ & 6600 & 12000 & 8900 \\
\hline Turkmenistan & 3531000 & & & 14000 & & & & & \\
\hline Ukraine & 39554000 & 375000 & $0.95 \%$ & & $12 \%$ & $71 \%$ & 44000 & 266300 & 197000 \\
\hline Uzbekistan & 19034000 & 80000 & $0 \cdot 42 \%$ & & & $36 \%$ & & 28800 & 21300 \\
\hline Median prevalence of injecting drug use & & & $0 \cdot 4 \%$ & & & & & & \\
\hline $\begin{array}{l}\text { Countries without HBsAg estimated } \\
\text { using median prevalence }\end{array}$ & & 142691 & & & $6 \cdot 8 \%$ & & 9700 & & \\
\hline $\begin{array}{l}\text { Countries without anti-HCV } \\
\text { estimated using median prevalence }\end{array}$ & & 18691 & & & & $46 \%$ & & 8600 & 6400 \\
\hline Total (rounded to nearest 1000 ) & & & & & & & 662000 & 2014000 & 1490000 \\
\hline \multicolumn{10}{|l|}{ Those in UE/EFTA } \\
\hline Austria $^{2}$ & 7087000 & 17500 & $0 \cdot 25 \%$ & & & $53 \%$ & & 9300 & 6900 \\
\hline Belgium $^{4}$ & 8790000 & 25800 & $0 \cdot 29 \%$ & & $3 \cdot 7 \%$ & $74 \%$ & 1000 & 19100 & 14100 \\
\hline Bulgaria $^{5}$ & 6606000 & 20250 & $0 \cdot 31 \%$ & & $5 \cdot 5 \%$ & $58 \%$ & 1100 & 11700 & 8700 \\
\hline Cyprus ${ }^{1}$ & 707000 & 446 & $0.06 \%$ & & $3 \cdot 5 \%$ & $36 \%$ & 20 & 200 & 100 \\
\hline Czech Republic $^{1}$ & 8875000 & 31200 & $0 \cdot 35 \%$ & & & $12 \%$ & & 3700 & 2700 \\
\hline Denmark $^{1}$ & 4476000 & 12754 & $0 \cdot 28 \%$ & & & $53 \%$ & & 6700 & 5000 \\
\hline Estonia $^{4}$ & 1140000 & 13801 & $1 \cdot 21 \%$ & & & $90 \%$ & & 12400 & 9200 \\
\hline Finland $^{3}$ & 4403000 & 15650 & $0 \cdot 36 \%$ & & & $42 \%$ & & 6600 & 4900 \\
\hline
\end{tabular}




\begin{tabular}{|c|c|c|c|c|c|c|c|c|c|}
\hline \multirow[b]{2}{*}{ Country } & \multirow[b]{2}{*}{$\begin{array}{l}\text { Population aged } \\
\geqslant 15 \mathrm{yr} \text { in } 2008\end{array}$} & \multicolumn{3}{|c|}{ Estimated number of current PWID* } & \multicolumn{2}{|c|}{ Prevalence } & \multicolumn{3}{|c|}{$\begin{array}{l}\text { Estimated numbers with infection } \\
\text { (rounded to nearest 100) }\end{array}$} \\
\hline & & Number & Prevalence & $\begin{array}{l}\text { Imputed from } \\
\text { median prevalence }\end{array}$ & HBsAg & Anti-HCV & HBsAg & Anti-HCV & $\begin{array}{l}\text { Chronic } \\
\mathrm{HCV}\end{array}$ \\
\hline France $^{3}$ & 50870000 & 122000 & $0 \cdot 24 \%$ & & & $45 \%$ & & 54900 & 40600 \\
\hline Germany $^{5}$ & 70748000 & 94250 & $0 \cdot 13 \%$ & & $2 \cdot 0 \%$ & $75 \%$ & 1900 & 70700 & 52300 \\
\hline Greece $^{2}$ & 9578000 & 8148 & $0.09 \%$ & & $2 \cdot 5 \%$ & $50 \%$ & 200 & 4100 & 3000 \\
\hline Hungary ${ }^{1}$ & 8511000 & 3941 & $0.05 \%$ & & $0 \cdot 5 \%$ & $23 \%$ & 20 & 900 & 700 \\
\hline Iceland & 249000 & & & 600 & & & & & \\
\hline Ireland $^{5}$ & 3506000 & 6289 & $0 \cdot 18 \%$ & & $0 \cdot 4 \%$ & $72 \%$ & 30 & 4500 & 3400 \\
\hline Italy $^{1}$ & 51260000 & 326000 & $0 \cdot 64 \%$ & & & $59 \%$ & & 193000 & 142800 \\
\hline Latvia $^{5}$ & 1943000 & & & 5500 & & $74 \%$ & & 4100 & 3000 \\
\hline Lithuania $^{4}$ & 2823000 & 5123 & $0 \cdot 18 \%$ & & $5 \cdot 9 \%$ & $73 \%$ & 300 & 3700 & 2800 \\
\hline Luxembourg $^{1}$ & 395000 & 1482 & $0 \cdot 38 \%$ & & $3 \cdot 9 \%$ & $81 \%$ & 100 & 1200 & 900 \\
\hline Malta $^{1}$ & 342000 & & & 900 & & $33 \%$ & & 300 & 200 \\
\hline Netherlands ${ }^{4}$ & 13553000 & 3115 & $0.02 \%$ & & $3 \cdot 0 \%$ & $77 \%$ & 100 & 2400 & 1800 \\
\hline Norway $^{1}$ & 3862000 & 10032 & $0 \cdot 26 \%$ & & $1 \cdot 2 \%$ & $74 \%$ & 100 & 7400 & 5500 \\
\hline Poland ${ }^{4}$ & 32389000 & & & 88000 & $4 \cdot 6 \%$ & $59 \%$ & 4000 & 51900 & 38400 \\
\hline Portugal $^{2}$ & 9076000 & 16425 & $0 \cdot 18 \%$ & & $5 \cdot 0 \%$ & $46 \%$ & 800 & 7600 & 5600 \\
\hline Romania $^{5}$ & 18157000 & & & 49000 & $10 \%$ & $64 \%$ & 5000 & 31400 & 23200 \\
\hline Slovakia $^{5}$ & 4536000 & 18841 & $0 \cdot 42 \%$ & & & $50 \%$ & & 9400 & 7000 \\
\hline Slovenia $^{1}$ & 1733000 & 7310 & $0 \cdot 42 \%$ & & $3 \cdot 4 \%$ & $22 \%$ & 200 & 1600 & 1200 \\
\hline Spain $^{3}$ & 37814000 & 83972 & $0 \cdot 22 \%$ & & & $73 \%$ & & 61600 & 45500 \\
\hline Sweden $^{5}$ & 7641000 & 29513 & $0 \cdot 39 \%$ & & & $88 \%$ & & 26000 & 19300 \\
\hline Switzerland ${ }^{1}$ & 6335000 & 31653 & $0 \cdot 50 \%$ & & & $78 \%$ & & 24700 & 18300 \\
\hline United Kingdom ${ }^{4}$ & 50210000 & 142650 & $0 \cdot 28 \%$ & & & $46 \%$ & & 65600 & 48600 \\
\hline Median prevalence of injecting drug use & & & $0 \cdot 3 \%$ & & & & & & \\
\hline $\begin{array}{l}\text { Countries without HBsAg estimated } \\
\text { using median prevalence }\end{array}$ & & 852534 & & & $3 \cdot 5 \%$ & & 29800 & & \\
\hline $\begin{array}{l}\text { Countries without anti-HCV estimated } \\
\text { using median prevalence }\end{array}$ & & 600 & & & & $59 \%$ & & 400 & 300 \\
\hline Total (rounded to nearest 1000) & & & & & & & 45000 & 697000 & 516000 \\
\hline Total Europe (rounded to nearest 1000) & & & & & & & 706000 & 2711000 & 2006000 \\
\hline
\end{tabular}

FYR, The Former Yugoslav Republic of Macedonia; Anti-HCV, antibodies to the hepatitis C virus; EU/EFTA, European Union and European Free Trade Association area; EU/EFTA HBsAg and anti-HCV data from EMCDDA website plus a literature search for Switzerland and Iceland $\left({ }^{1}\right.$ National study; ${ }^{2}$ weighted mean of national studies; ${ }^{3}$ multi-city; ${ }^{4}$ weighted mean from city/sub-region studies; ${ }^{5}$ one city/region.)

* Mathers et al. [26], plus data for Bosnia \& Herzegovina, Croatia, Czech Republic, Cyprus, Estonia, Greece, Luxembourg, Macedonia, Portugal, Sweden, and United Kingdom from EMCDDA website; and data for Serbia from the Republic of Serbia UNGASS Country Progress Report on AIDS 2010. 
HCV RNA. Prevalence of these infections was highest in PWID ( $15 \%$ and $44 \%$, respectively). Although the estimates here need to be viewed with caution, they do suggest a sizable burden due to these two viral infections in the Region, particularly outside the EU/EFTA area.

First, it is important to consider the limitations of this study. The prevalence data on $\mathrm{HBsAg}$ and anti-HCV were obtained from literature searches, while grey literature was included, it is possible studies will still have been missed particularly if they have recently been undertaken, reported in languages other than Russian or English, or unpublished. Second, measures of the prevalence of HBsAg and anti-HCV were not identified in all populations or in all countries. In many countries no national studies had been undertaken, thus local and regional data were assumed to be reflective of the whole country. Small studies $(n<100)$ and those where population was not specifically or clearly defined were excluded; however, we did not asses the methodological quality of the studies, in part because data available was often limited. The studies used a range of designs and thus the robustness of the resulting data is likely to be variable. Where no measure of prevalence was found, simple imputation approaches were applied. Considering these limitations it is important that the findings are viewed cautiously. Even so, the extensive nature of searches undertaken in this assessment mean that it is likely to provide as robust an estimation as is currently practical at the regional level.

In the WHO European Region outside the EU/ EFTA, the measured HBsAg and anti-HCV prevalences were highest in PWID, but infection was also common in the general population $(3 \cdot 8 \%$ and $2 \cdot 3 \%$, respectively), MSM $(8 \cdot 7 \%$ and $4 \cdot 2 \%$, respectively), and in sex workers $(3 \cdot 3 \%$ and $11 \%$, respectively). There was substantial variation between countries, while prevalence of these infections in PWID was high in most countries; Uzbekistan had a prevalence of $13 \%$ for both infections in the general population. The general population $\mathrm{HCV}$ prevalence estimate was also elevated in the Ukraine and Georgia, and in Albania the general population HBsAg prevalence estimate was elevated. While these differences might be related to the methodologies used in the studies, they warrant further investigation.

For the general population, PWID and MSM prevalences were higher than in the EU/EFTA area [7], although comparable data for EU/EFTA was very limited for MSM. The ECDC review [7] found only two studies from the EU/EFTA countries that had measured HBsAg in MSM $[4 \%$ Sweden 1993-1997, and <1\% UK (Scotland) 1993-2003] and one study that had measured anti-HCV $[1 \cdot 3 \%$ Amsterdam (The Netherlands) 2003], indicating a need for further studies of prevalence for MSM and other transmission risk populations. For sex workers data on the prevalence of these infections has not been reviewed for the EU/EFTA area, but considering the elevated prevalence found here this is needed. In the countries outside the EU/EFTA, MSM have a higher prevalence of both HBsAg and anti$\mathrm{HCV}$ than the general population, and sex workers had higher anti-HCV prevalence. The high antiHCV prevalence in MSM and sex workers possibly reflects an overlap with the PWID population [8]. The higher prevalences of both infections in MSM is a concern considering the evolving epidemic of HIV in this group in parts of central and eastern Europe [28].

The ratios between the general population estimates and the blood-donor estimates were higher for the EU/EFTA area compared to outside (almost three times higher for HBsAg and about five times higher for anti-HCV). The reasons for this difference are unclear, but it could for example, be due to more success in excluding those who have been at risk of infection from blood donation in the EU/EFTA countries, or be a reflection of the higher prevalence of these infections in the general population outside the EU/EFTA area. This difference needs further investigation.

The estimates of the numbers infected simply applied prevalence to population data; with the prevalences derived from studies using a range of methodologies and imputed for countries with no data (the majority lacked a general population HBsAg estimate). There is some corroboration for the estimates obtained from comparison with published national estimates for HCV. In Italy a modelling approach estimated $2 \cdot 1$ million people chronically infected with $\mathrm{HCV}$ in 2000 and 1.9 million in 2005 [29] compared to the $2 \cdot 0$ million estimated here. In the UK, modelling approaches suggest that around 200000 people are living with chronic HCV infection [30, 31], while the simple UK estimate here $(n=260100)$ is higher it is within the confidence range.

For the PWID estimates there is some corroboration from the UK, where 66000 current PWID were estimated as HCV-infected in England and 
Wales [30] compared to the simple UK estimate here of 48600 - though the study had estimated a larger injecting population than the one used here. The estimates of the number of infected PWID obtained here will be particularly uncertain, as estimates of infection prevalence are being simply applied to estimates of the number of current PWID. Both of these are difficult to measure due to the illicit and marginalized nature of injecting drug use, and are thus are likely to be subject to much uncertainty. The estimated number of PWID should thus be used very cautiously. In the UK almost as many former PWID were estimated to have HCV as current PWID [30]. The estimates obtained here relate to number of infected current PWID, but there will also be many former PWID that will have been infected. It is thus likely that many of the infections in the region not in current PWID will be in former PWID.

A previous estimate had suggested that 14 million people were living with chronic HBV [32] in the WHO European Region, although the method used for this estimate is not given, it provides some corroboration for the 13.3 million estimated here. In the 1990 s, it was estimated from national prevalence data, that there were 8.9 million people living with $\mathrm{HCV}$ [4] in the WHO European Region (prevalence $1 \cdot 0 \%$ ), our estimate suggest that $\mathrm{HCV}$ infection might have increased over time to 15 million (prevalence $2 \cdot 0 \%$ ). If so, this might reflect transmission in PWID, particularly in the east of the Region, where there has been a recent and accelerating epidemic of HIV in PWID [33].

Viral hepatitis has been recognized as a global public health problem and a World Health Assembly Resolution [34] has called on Member States to take action to strengthen preventive and control measures. Our findings indicate a large pool of individuals infected with HBV and HCV in the WHO European Region, and so the potential for further transmission. The WHO's recent Framework for Global Action to prevent and control viral hepatitis [1] describes the work needed. Interventions to prevent transmission $[2,9,35]$, including information on safer sex, condom distribution, needle and syringe programmes, and strict infection control practices in healthcare and other settings, need to be maintained and expanded as appropriate. HBV can be prevented through vaccination, national policies should be reviewed regularly, and in those countries with universal vaccination programmes targeted vaccination of high-risk groups should be considered, as recommended by WHO [36]. Both HBV and HCV can, to varying degrees, be successfully treated. Easy access to diagnostic testing is an important entry point for accessing both prevention and treatment programmes, and in higher prevalence countries targeted screening programmes should be considered for those at greatest risk. Other measures can also reduce the transmission of viral hepatitis, such as, ensuring a safe blood supply.

This study provides useful data for policy makers on the scale of HBV and HCV infection in the region. Policy makers need consider the extent of these diseases when planning health services in order to ensure that appropriate interventions [35-37] are provided on a sufficient scale to reduce the burden arising from these two preventable infections.

These findings indicate that there may be over 13 million adults living with $\mathrm{HBV}$ and 15 million with HCV in the WHO European Region - indicating a large burden for treatment and care. The prevalence of these infections appears to be higher outside the EU/EFTA, with these countries (mainly in eastern Europe and central Asia) accounting for $66 \%$ of those with HBsAg and $64 \%$ of those with $\mathrm{HCV}$ RNA, yet only $42 \%$ of the European Region's adult population (Table 4). Efforts to prevent, diagnose and treat these infections need to be maintained and improved. Surveillance of the seroprevalence of these infections and related risk behaviours in the affected populations is needed to monitor trends and allow assessment of the impact of interventions.

\section{SUPPLEMENTARY MATERIAL}

For supplementary material accompanying this paper visit http://dx.doi.org/10.1017/S0950268813000940.

\section{ACKNOWLEDGEMENTS}

This work was funded by the World Health Organization Regional Office for Europe. The authors thank Dr Lucy Platt for her assistance with the literature in Russian.

\section{DECLARATION OF INTEREST}

None.

\section{REFERENCES}

1. WHO. Prevention and control of viral hepatitis infection: frame work for global action 2012. Geneva: WHO, 2012 (www.who.int/csr/disease/hepatitis/GHP_ framework.pdf). Accessed 14 December 2012.

2. Lavanchy D. Hepatitis B virus epidemiology, disease burden, treatment, and current and emerging prevention 
and control measures. Journal of Viral Hepatitis 2004; 11: $97-107$.

3. Goldstein ST, et al. A mathematical model to estimate global hepatitis B disease burden and vaccination impact. International Journal of Epidemiology 2005; 34: 1329-39.

4. World Health Organization. Hepatitis C - global prevalence (update). Weekly Epidemiological Record 1999; 74: 425-27.

5. WHO Executive Board. Viral hepatitis. Report by the Secretariat. EB126/15. Geneva: WHO; 12 November 2009: http://apps.who.int/gb/ebwha/pdf_files/EB126/ B126_15-en.pdf.

6. Perz JF, et al. The contributions of hepatitis B virus and hepatitis $\mathrm{C}$ virus infections to cirrhosis and primary liver cancer worldwide. Journal of Hepatology 2006; 45: 529-538.

7. European Centre for Disease Prevention and Control. Hepatitis B and C in the EU neighbourhood: prevalence, burden of disease and screening policies. Stockholm: ECDC; September 2010 (www.ecdc. europa.eu/en/publications/Publications/TER_100914_ Hep_B_C\%20_EU_neighbourhood.pdf).

8. Platt L, et al. The HIV epidemics of Europe: vulnerability and response. World Bank (in press).

9. Lauer GM, Walker BD. Hepatitis C virus infection. New England Journal of Medicine 2001; 345: 41-52.

10. Munir S, et al. Hepatitis C treatment: current and future perspectives. Virology Journal 2010; 7: 296.

11. Lee WM. Medical progress: hepatitis B virus infection. New England Journal of Medicine 1997; 337: 1733-1745.

12. Hagan H, Des Jarlais DC. HIV and HCV Infection among Injecting Drug Users. Mount Sinai Journal of Medicine 2000; 67: 423-428.

13. Matthews GV, et al. Patterns and characteristics of hepatitis $\mathrm{C}$ transmission clusters among HIV-positive and HIV-negative individuals in the Australian Trial in Acute Hepatitis C. Clinical Infectious Diseases 2011; 52: $803-811$.

14. Lauer GM, Walker BD. Hepatitis C virus infection. New England Journal of Medicine 2001; 345: $41-52$.

15. Sorrell MF, et al. National Institutes of Health Consensus Development Conference Statement: Management of Hepatitis B. Annals of Internal Medicine 2009; 150: 104-110.

16. National Institutes of Health. Consensus development conference statement: management of hepatitis C: 2002-10-12 June, 2002. Hepatology 2002; 36: S3-20.

17. European Association for the Study of the Liver. EASL clinical practice guidelines: management of chronic hepatitis B. Journal of Hepatology 2009; 50: 227-242.

18. Ghany MG, et al. Diagnosis, management, and treatment of hepatitis C: an update. Hepatology 2009; 49: 1335-1374.

19. Vickerman P, Martin N, Hickman M. Can Hepatitis C virus treatment be used as a prevention strategy? Additional model projections for Australia and elsewhere. Drug and Alcohol Dependence 2011; 113: 83-85.

20. Seeff LB. Natural history of chronic hepatitis C Hepatology 2002; 36 (Suppl. 1): S35-S46.

21. Toy M, et al. Potential impact of long-term nucleoside therapy on the mortality and morbidity of active chronic hepatitis B. Hepatology 2009; 50: $743-751$

22. Hutton DW, et al. Cost-effectiveness of screening and vaccinating Asian and Pacific Islander adults for hepatitis B. Annals of Internal Medicine 2007; 147: 460-469.

23. Directorate for the Quality of Medicines and Health Care of the Council of Europe. The collection, testing and use of blood and blood components in Europe: 2006 Report. Council of Europe Publishing, Strasbourg, 2010.

24. World Health Organization. World Health Statistics 2010. Geneva, World Health Organization, 2010.

25. Micallef JM, Kaldor JM, Dore GJ. Spontaneous viral clearance following acute hepatitis $\mathrm{C}$ infection: a systematic review of longitudinal studies. Journal of Viral Hepatitis 2006; 13: 34-41.

26. Mathers B, et al. Global epidemiology of injecting drug use and HIV among people who inject drugs: a systematic review. Lancet 2008; 372: 1733-1745.

27. EMCDDA. Statistical Bulletin 2010 (www.emcdda. europa.eu/stats10/pdu). Accessed 6 May 2011.

28. Bozicevic I, et al. HIV epidemics among men who have sex with men in central and eastern Europe. Sexually Transmitted Infections 2009; 85: 336-342.

29. Mariano A, et al. Estimating the incidence, prevalence and clinical burden of hepatitis C over time in Italy. Scandinavian Journal of Infectious Diseases 2009; 41: 689-699.

30. Harris R, et al. Hepatitis C prevalence in England remains low and varies by ethnicity: an updated evidence synthesis. European Journal of Public Health 2012; 22: 187-192.

31. Scottish Government. Hepatitis C Action Plan for Scotland: Phase II (May 2008-March 2011). Edinburgh: Scottish Government, May 2008 (www. scotland.gov.uk/Resource/Doc/222750/0059978.pdf). Accessed 8 December 2011.

32. European Hepatitis B Expert Group. European orientation towards the better management of hepatitis in Europe. Recommendations of the Hepatitis B expert group, 2008 (www.elpa-info.org/tl_files/elpa downloads/hep_b.pdf). Accessed 14 December 2012

33. Jolley E, et al. HIV among people who inject drugs in Central and Eastern Europe and Central Asia: a systematic review with implications for policy. British Medical Journal. Published online: 18 October 2012. doi: 10.1136/bmjopen-2012-001465.

34. WHA. Sixty-third World Health Assembly: viral hepatitis. WHA63.18. Geneva: WHO, 21 May 2010 (http:// apps.who.int/gb/ebwha/pdf_files/WHA63/A63_R18-en. pdf). Accessed 14 December 2012 
35. Brook G, Soriano V, Bergin C. European guideline for the management of hepatitis $\mathrm{B}$ and $\mathrm{C}$ virus infections, 2010. International Journal of STD \& AIDS 2010; 21: 669-678.

36. WHO. Hepatitis B vaccines. WHO position paper. Weekly Epidemiological Record 2009; 84, 405-420.
37. WHO Regional Office for Europe. European Action Plan for HIV/AIDS 2012-2015. Copenhagen, WHO Regional Office for Europe, 2011 (www.euro.who.int/ en/what-we-do/health-topics/communicable-diseases/ hivaids/publications/2011/european-action-plan-forhivaids-20122015). Accessed 8 December 2011. 